\title{
Towards regional economic development in South Africa: Conceptualising the 'region' associated with economic development through the Durban Aerotropolis
}

\begin{abstract}
This paper critically considers the conceptualization of the 'region' in regional economic development. It utilizes the Durban Aerotropolis in KwaZulu-Natal, South Africa as a case of reference through which the conceptualization and underpinnings of 'region' associated with economic development are understood. This exercise is prompted by the nomenclatural shifts in local government from local economic development to regional economic development which is causing shifts in approaches to the implementation of economic development projects. The findings presented in this paper show that in the conceptualisation of the region in the instance of the Durban Aerotropolis, understanding the function, form and scale of a regional economic development project becomes pertinent to the social construction of the region with consequences for the project focus and implementation. In the discussion, function is examined as the purpose of a regional economic development project, form refers to the kind of economic development mechanism or strategy which could assist in fulfilling that purpose and scale speaks to the extent, reach and magnitude of the project, without which the implications are challenging practical enactment or implementation of regional economic development projects. The social constructions of region outlined in this paper thereby attest to the multiplicity of definitions which are typically based on the context in which the concept is being used and thus shows the 'region' inherent in regional economic development as produced through, and for, an assemblage of economic activity in space. From this we understand the region in regional economic development to be a social construct which presents itself as an assemblage of economic activity in space. Although we understand regions as spatially contingent, the theoretical and empirical conceptualisation of regions within regional economic development planning, policy-making and practice must draw on the specifics of contextuality to ensure its utility to economic development.
\end{abstract}

Keywords: region, regional economic development, aerotropolis, airport city, Durban

\section{Introduction}

Because of the high levels of poverty and the decentralisation of government, local governments in South Africa, as the key agents of Local Economic Development (LED), are faced with the responsibility of both improving the formal market economy and fostering and 
supporting the informal or lower end of the economic spectrum (Nel \& Rogerson, 2005). Thus, in the South African context, LED is expected to pursue both socio-economic redress and economic development ( $\mathrm{Nel} \&$ Rogerson, 2016). Competition between these agendas, compounded by the absence of a uniform central state policy, complicates LED practice as practitioners are unclear about whether they should prioritise pro-poor or pro-growth, marketled LED (Nel \& Rogerson, 2016). This often leads to local governments tending to revert to pro-poor, government-driven projects rather than economically-driven interventions through their LED units (Rogerson, 2010; Rogerson \& Rogerson, 2012; Nel \& Rogerson, 2016). Consequently, local understanding, resource allocation, project delivery, and the sustainability of LED outcomes has been weak (Nel \& Rogerson, 2016).

Recently, these ongoing challenges and the limited success of LED have led policy makers to consider the need for a regional focus for economic development in addition to the local scale. Regional Economic Development (RED) is seen to offer a more strategic economic development approach which supersedes community-focussed endeavour. Furthermore, RED is believed to create opportunities for a more cooperative development approach for interlocal relations (i.e. relations between neighbouring local governments), in contrast to the LED approach in which local governments are inward looking and often compete with each other in seeking to attract resources and investment into local communities (Olberding, 2002). Stemming from these shifts, projects which are intended to be catalytic of regional economic development have begun to emerge in South Africa (Luthuli, 2013). For example, the invoking of Special Economic Zone policy to promote foreign investment into South Africa and the popularity of aerotropolis developments to leverage growth associated with airports in cities. In its 2015 Aerotropolis Strategy for the province, the KwaZulu-Natal Department of Economic Development, Tourism and Environmental Affairs (EDTEA) promoted the Durban Aerotropolis as a powerhouse for regional economic development with the role of stimulating regional economic interconnectivity, job creation and growth.

While the practice of Regional Economic Development begins to unfold in South Africa, theorists, such as Van Langenhove (2013), assert that the concept of the region is polysemous i.e. that there is uncertainty in its meaning because it is understood variably by different actors and across disciplines. Conceptual vagueness, although it provides for flexibility, has theoretical and empirical consequences, including implications for policy implementation (Van Longenhove, 2013) and, in this particular case, for the enactment of RED as a driver of change. This study thus examines the Durban Aerotropolis as a regional economic development project with the intention of more fully understanding the conceptualisation of the 'region' as a core component of RED as it is emerging in South Africa. An understanding of the region is seen as especially important given the ongoing need for sustainable economic transformation in the wake of the challenges associated with LED and the limited experience of implementing RED within South Africa. Furthermore, a stronger understanding of the region will limit the potential pitfalls which may emerge if RED projects are based on fuzzy conceptualisations of what the region entails.

\section{Theoretical conceptualisations of 'region'}

As a basis for examining the conceptualisation of the 'region' associated with the Durban Aerotropolis, the following discussion presents a brief overview of the numerous ways in which regions have been theorised as social constructions. 
While every geographical surface can potentially be called a region, Van Langenhove (2013) contends that regions are much more than just geographical realities and that they should not be defined only by their surface or boundaries since they are "institutional facts". By this he means that regions should be those geographical surfaces that are only 'facts' by human agreement because they are geographical areas whose existence is impossible without social construction. From this social constructionist point of view, regions come to exist because they are being talked about and because of the way they are talked about (Van Langenhove, 2013). Thus, a region is constructed through discourses such as those related to governance, politics, culture and economics (Paasi, 2011). Equally a region can be constructed through discourses which articulate several conceptualisations of space (whether absolute, relative or relational) (Hubbard et al, 2008).

Regions have been conceptualised through disciplines such as geography, political science and economics as comprising of a geographical space, an economic interaction, an institutional or governmental jurisdiction, or as having social and cultural characteristics (Keating, 1998; Mattli, 1999; Farrell et al., 2005; Hooghe \& Marks, 2009; Goodwin, 2013). These notions of region have typically been constructed as fixed and bounded territories or as relationally-produced flexible territories Thus regions can be "well defined with sharp boundaries or ... fuzzy" (Van Langenhove, 2013: 476). Furthermore, whether constructed as fixed or flexible, the scale of regions can differ. According to Van Langenhove (2013), in considering scale, the distinction between regions can be at three levels: sub-national level (within a nation as a whole), supra-national level (an integration of countries), and crossborder level (across national boundaries or across political jurisdictions). For instance, there are economic and political macro-regions and regionalisms such as the European Union and the African Union. There are also global city regions as well as polycentric urban regions (Paasi, 2011).

According to Suorsa (2014), in the traditional (fixed) view of regions there are three classifications: administrative regions, functional regions and formal regions. Administrative regions are classified by governance and political territories; functional regions by labour market areas, and formal regions by their human-made and physical features (Claval, 1998; Paasi, 2009). Those studying regions through the territorial lens emphasise that regions are discrete spaces and defined territories that are controlled by actors and can be managed as economic, political and social spaces (Goodwin, 2013; Thomas et al., 2013). Paasi (1986) stipulates that the territoriality of a region can only be achieved once the region establishes its boundaries and becomes identified as a distinct unit in the spatial structure of society. In many cases, political institutions lend themselves to the language of territory, fixity, boundaries and boundedness as elements of regionality (Paasi, 2002; Jones \& Macleod, 2004; Paasi, 2004; Hudson, 2006; Allen \& Cochrane, 2007). This traditional classification is reflective of a realist view of regions as it regards them as concrete and existing entities or actual 'things' that are 'out there' rather than 'things' dependent on observers (Suorsa, 2014).

Challenging the territorial understanding of regions is a relational view which shifts the focus from thinking of regions as bounded territories which need to be managed, protected or administered; to seeing them as 'products' of complex sets of social relationships whose density and variety changes in time and space (Suorsa, 2014). The relational point of view disavows the territorial view of regions and proposes instead that an adequate understanding of the region can only come about from a conception of places as "open, discontinuous, relational and internally diverse" (Allen et al., 1998: 143). From this perspective, regions cease to be whole, bounded and closed entities and instead are seen as dynamic and 
proactive; more like "networks of concentrations of people and places than simply uniform and bounded geographical units" (Suorsa, 2014: 208). In this vein, cities and regions are described as "sites within networks of varying geographical composition as well as spaces of movement and circulation of goods, technologies, knowledge, people, finance, and information" (Amin et al., 2003: 25). Further to this relational argument, we find that emerging spatial configurations are no longer interpreted as territorial and bounded (Macleod \& Jones, 2007) because they are made up of a web of networks and relational "connections", which are neither fixed nor located in place but are constituted through various "circulating entities" (Latour, 1999), and which subsequently, "bring about relationality both within and between societies at multiple and varied distances" (Urry, 2007: 28).

Advancing the relational conceptualisation of regions, are those theorists which consider a region as an assemblage - as "the product of the networks, interactions, juxtapositions and articulations of the myriad of connections through which all social phenomena are lived out" (Allen et al., 1998: 50). Gregory (2000) argues that regional formations are more or less temporary concentrations of institutions, objects, people, and practices that are involved in the operation and outcome of local, trans-local and trans-regional processes. This relational view of the region as an assemblage captures what Massey (2005) refers to as a 'throwntogetherness' and which Hubbard et al. (2008) refer to as a coming together of diverse elements that cross categories such as the natural and social.

According to Goodwin (2013), this assemblage could also be of overlapping institutional forms such as regional offices, agencies, boards and assemblies, along with related strategies. These institutional forms are territorial entities that attempt to be the foundation that "holds down the fluid elements of global life in the interest of their regions... [in order to] generate fixity through processes of government and governance" (Goodwin et al., 2005: 423; Allen \& Cochrane, 2007). In this perspective, the assemblages that make up a region can potentially be derived from aspects of the relational and territorial theorisations of regions. The coming together of the various networks and interactions may be happening simultaneously in spaces of flows and in spaces of places (Castells, 2000) such that 'regional' spatial assemblages are not exclusively regional, but bring together elements of central, regional and local institutions (Allen \& Cochrane, 2007).

The following section presents a background to aerotropolis developments as a mechanism of economic development which is often argued to facilitate increased economic activity within a region.

\section{From airports to airport cities: The Aerotropolis as a mechanism for regional economic development}

Traditionally, airports have served aircraft passengers and cargo. This core functionality has expanded to encompass a broader conceptualisation in which airports are seen as key nodes in global production and commercial systems and are increasingly anticipated to be engines of local economic development, attracting air-commerce-linked businesses (Kasarda, 2001a). Thus, in addition to their core aeronautical infrastructure and services, airports have developed non-aeronautical commercial facilities and services (Kasarda, 2006). Airports have incorporated a variety of commercial functions into passenger terminals as well as the landside development typically required for research parks, entertainment and conference facilities, residential developments, and district-zoned spaces for specific industrial activity 
such as foreign trade zones (Arend et al., 2004). Airports have thus become complex multifunctional enterprises, serving both aeronautical development (traditional airport functions) and commercial development (terminal and landside activities; Kasarda, 2006).

With the rise of airports' non-aeronautical function and activity, there has been a transformation of city airports into airport cities (Kasarda, 2006; Peneda et al., 2011). An airport city can be called an 'aerotropolis' (Kasarda, 2006), which is essentially an airportdriven urban development node (Kennedy et al., 2014). The thinking around the aerotropolis concept is that developments associated with the airport facilitate the emergence of corridors, clusters and spines of airport-related businesses that will create new urban forms as much as 100 kilometres or more from major airports (Kasarda, 2000; Arend et al., 2004). As an aerotropolis, the airport functions as "a multimodal convergent nucleus and commercial nexus of airport integrated urban complex, analogous to the function central business districts play in the traditional metropolis" in which commercial and business activity is concentrated (Kasarda, 2001a: 44).

In South Africa, there are a number of aerotropolis development programmes being rolled out, largely in relation to brownfields sites where pre-existing airports and adjacent industrial landscapes are being rethought to serve as the more integrated, efficient and productive spaces of an aerotropolis (Menon, 2014). Integral to the arguments for the development of aerotropoli in South Africa and globally, is the fostering of regional economic development (RED) (EDTEA, 2015). RED has been conceptualised as the outcome of generative economic activity through collaborative multi-stakeholder relationships, productive networks and mutually reinforcing relationships drawing on key economic assets and infrastructure that contributes to an increase in the general prosperity of a region. Bodhanya (2015) defines RED as the sustained and concerted actions of policy makers, businesses and communities that promote the economic health of a specific geographic region generally below the level of the nation state. However, when it comes to an aerotropolis being a catalyst for regional economic development in South Africa, and elsewhere, the particularities of how an aerotropolis is understood to encompass regional activities, which produce socio-economic impacts in a region, rise to the forefront of consideration. Key concerns therefore centre around what spatial forms are an aerotropolis and its associated region comprised of? How are these spatial forms being produced? What region/s will be economically developed through the growth of an aerotropolis? In what ways?

Emerging from consideration of the shifts from local to regional economic development approaches; the theorisation of regions; and the aerotropolis as a development mechanism, the discussion which follows uses the aerotropolis development in Durban as a case through which to analyse the complex notion of region as a core element of RED.

\section{Methodology}

An exploratory research design was selected for the qualitative study undertaken within a social constructivist paradigm. A purposive sampling approach with non-probability sampling was used to derive a sample from which primary data was sourced. The data was collected through 23 in-depth, face-to-face interviews and relevant documentary sources, all of which were analysed using a thematic approach 
The interview sample was selected from the population of government departments, government-funded institutions or state-owned entities, and private sector companies that were involved in the Durban Aerotropolis and in driving regional economic development within KwaZulu-Natal. There was no exact number to serve as a determining factor of size of population given that these are big organisations and vary according to sectors and in relation to project engagements. Within each of these organisations were individuals and, at times, teams that dealt directly with the various aspects of the Durban Aerotropolis. The sample therefore included first and foremost the project Aerotropolis partners, namely the Department of Economic Development, Tourism and Environmental Affairs, Dube TradePort, Airports Company South Africa (ACSA), eThekwini Municipality, Tongaat Hulett Property Developers (THPD), Tourism KwaZulu-Natal, and Trade and Investment KwaZulu-Natal. Also included were members of the Economic and Strategic Infrastructure Development Cluster: iLembe Municipality, iLembe Chamber of Commerce, Department of Corporative Governance and Traditional Affairs, Department of Transport, and Small Business Growth Enterprise. In addition, three private sector companies working within the Dube TradePort were selected.

Other primary data sources were documentary evidence from within these organisations, such as annual reports, strategy documents and factsheets. Of these documents, two critical sources provided a detailed insight to the process of planning an aerotropolis as a regional economic development mechanism, namely, and the Durban Aerotropolis Masterplan (EDTEA, 2016) and the KwaZulu-Natal Provincial Spatial Development Framework (KZN Planning Commission, 2011).

In this study, it is important to note that perspectives and plans emerge from the interplay between a socially constructed self and a socially constructed environment and that the self and the specific setting are lent an additional structure by their location and time (Babbie \& Mouton, 2009). Given the above-mentioned factors, the Miles and Huberman (1994) thematic analysis approach was used in data analysis. A transcription of interviews and field notes was produced to enable the data reduction process. The transcriptions were then coded to establish general descriptive codes for topics raised in the data and to identify clusters and hierarchies of information to identify patterns and relationships (Miles \& Huberman, 1994; de Wet \& Erasmus, 2005). Through the coding process, patterns and themes were identified in the data and were then interpreted in the light of the conceptual framework and research questions to produce the findings of the study. Through this exercise it became apparent that the way in which interviewees from the Durban Aerotropolis spoke of the geography of the project reflected the form, function and scale of the region. These findings, which address the conceptualisation of region in the light of regional economic development, are presented below.

\section{The Durban Aerotropolis}

The Durban Aerotropolis is envisaged as a hub of trade and business in Africa, which is "about to become South Africa's new gateway to the Southern African region" (Dube TradePort, 2017). It is planned as a freight-oriented development with a purpose-built, worldclass logistics hub incorporated into a 'greenfield' site near the northern boundary of the eThekwini Municipality in Durban and adjacent to areas characterised by ongoing intensive economic, residential and infrastructure development (see Figure 1). The Aerotropolis has the King Shaka International Airport and the Dube TradePort at its centre. The airport was 
opened in 2010 and currently serves 4,7 million passengers flights (ACSA, 2018) and 600 tonnes of cargo flights per week (Dube TradePort, 2018). Dube TradePort is a state-owned entity which is a hub of trade and business in Africa, about to become South Africa's new gateway to the Southern African region (Dube TradePort, 2017). The role of the TradePort is further to grow and manage the newly enacted special economic zone associated with the airport. In November 2017, the 60-year masterplan for the Durban Aerotropolis development was completed through a consultative process which included a host of stakeholder groups in the public and private sectors, led by provincial government. The masterplan highlights the anticipation of stakeholders that the airport city, together with the existing seaport infrastructure in Durban harbour, will facilitate access to numerous global destinations and linkages to countries within the Southern African Development Community region as well as positioning KwaZulu-Natal as a key business point within South Africa (Dube TradePort, 2017).

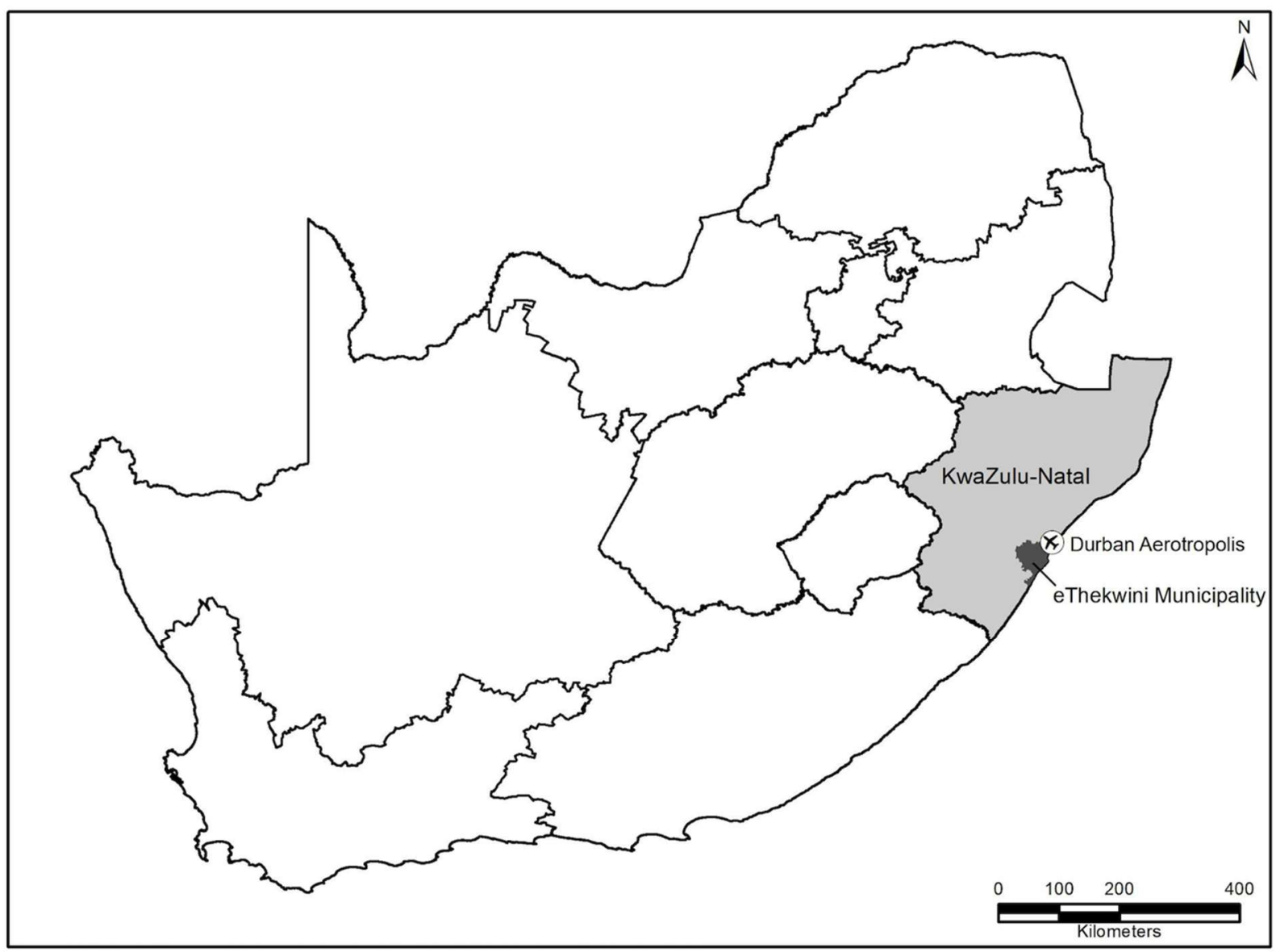

Figure 1: Location of the Durban Aerotropolis (illustration: Nomkhosi Luthuli).

\section{Notions of 'region' associated with the Durban Aerotropolis}

Thematic analysis of key informant interviews in regard to the conceptualisation of the region in relation to the Durban Aerotropolis reveals that the function, form and scale of the Aerotropolis are important elements through which a region can be understood within the framework of a regional economic development approach. Function can be understood as the purpose of an RED project; form refers to the kind of economic development mechanism or strategy which could assist in fulfilling that purpose, and scale speaks to the extent, reach and magnitude of the project activities and outcomes. 
Notions of the form, function and scale of the region were cited by the interviewees as being related to the following issues:

1. The purpose that the Durban Aerotropolis seeks to serve and the requirement needed to fulfil that purpose (function)

2. The consequent thoughts that went into decisions about what kind of economic development mechanism or strategy could fulfil the identified purpose (form)

3. The extent, reach and magnitude of the project that needed to be considered (scale)

In the light of these concerns, and since form follows function (Kasarda \& Appold, 2014), the findings presented here firstly capture the conceptualisation of the functions of the Durban Aerotropolis, followed by consideration of the form and scale associated with the airport city project. This then leads to an analysis of the notion of 'region' as it pertains to RED in the South African context.

\section{Conceptualisations of the function of the Durban Aerotropolis}

The conceptualisations of the function of the Durban Aerotropolis reveal the purpose of the project as constructed by respondents and in related strategic documents. This section therefore portrays the many ways in which the project is constructed as an integrated environment with a mixed-use function. These functions include the Durban Aerotropolis being perceived as a space to live work and play, a space for innovation, a space for basic services, a space for industry, a space for world-class logistics, and a space for food production. The presentation of the Durban Aerotropolis in this way corresponds with Kasarda's (2006) explanation that airports have become complex multi-functional enterprises that serve both aeronautical and commercial development.

According to the Chief Executive Officer (CEO) of the Dube TradePort (interview, 12. May 2016), the Durban Aerotropolis is an integrated environment and a mixed-use space. He has aspirations for the project in which it becomes an "integrated environment where you can actually have production as an industrial, you can have commercial office, retail, you can have educational [spaces], which is super important, and training... and then specialist things like special economic zones because the whole aerotropolis won't be a special economic zone. So special economic zones, certain shared infrastructure, so let's say rail, road, bulk infrastructure. Then other specialist zones would be like aviation linked." This understanding is in line with Hanly's (2015:1) reference to an aerotropolis as a "sub-regional economy where the airport city is the anchoring economic hub associated with a concentrically expanding mix of clustered uses".

Furthermore, when asked what spaces the aerotropolis encompasses, the Director for Research and Development at EDTEA (interview, 1. July 2016) said; "it should encompass the spaces of work, the spaces of living and the spaces of recreation". As with the above response, the Durban Aerotropolis Masterplan also showed that stakeholders seek to create a region within which "people will enjoy a holistic quality of life... where people can be able to enjoy a convenient and healthy live, work and play lifestyle" (EDTEA, 2016). Proposals have been made for a number of housing developments, many of which have a holistic and sustainable work-live-play basis to them to ensure "better located, better planned housing in the region" (Director for Research and Development at EDTEA, interview, 1. July 2016). One example is the very large housing estate and neighbourhoods of Cornubia just south of the King Shaka International Airport (EDTEA, 2016). Inevitably, as the aerotropolis region grows and expands, the need for new housing will arise and if these associated housing 
developments are well planned and implemented there are significant opportunities to undo the legacy of racial segregation that is still evident in the northern region of Durban. The 'live, work and play' narrative presented by stakeholders, which encompasses mixed-use function and a good quality lifestyle, is in line with Kasarda's (2001a) argument that need for travelling long-distances to work within the airport city can be eliminated if housing, commercial and leisure facilities are integrated with the development of corporate headquarters, regional offices and various professional organisations that gather around the airport.

Further to being developed as a space to live, play and work, there are some interviewees that conceive of the Durban Aerotropolis as a space for basic services. According to the Deputy Director of Policy and Planning at EDTEA (interview, 20. May 2016), the Durban Aerotropolis should not just be "limited to manufacturing, manufacturing, manufacturing". Here the respondent is advocating for a space where the people who work and live in the Durban Aerotropolis are able to access the basic services that they require. This includes but is not limited to schools, hospitals, police stations, fire station and many other services that are required for great living.

The Durban Aerotropolis is also functionally conceptualised as a development which produces innovation in response to global change. The masterplan identifies the following megatrends, "urbanisation, a rising, more empowered middle class, constrained, finite resources, hyper connectivity, the exponential growth of technology and innovation and the renaissance of design and innovation" (EDTEA, 2016). Innovation is prioritised within the Durban Aerotropolis masterplan as an active goal of the aerotropolis and within the flexibility built into the planning for a sustainable future through a competitive aerotropolis in Durban. According to the Director of Research and Development at EDTEA (interview, 1. July 2016), the aerotropolis provides spaces of innovation where people can do things in ways that have never been done before. The respondent further believes that within this space of innovation people should compete and set up their business ventures to avoid relying on the government to provide opportunities for employment. This innovation is also believed to result from companies working together (or coming together in space) to foster a clustered innovation and industrial environment.

According to the Durban Aerotropolis Masterplan, the project offers prime land for industrial activity within a reasonable distance to King Shaka International Airport (EDTEA, 2016). This further highlights the Durban Aerotropolis functionality as a space for industry and innovation. The space for industrial activity has been designated as the Special Economic Zone, a project managed by the Dube TradePort Corporation as an entity which forms part of the Durban Aerotropolis. Like some of the world's best aerotropoli, for example, in Brazil and China, decisions have been taken to attract industry, foster business development and create jobs by setting up and establishing SEZs within the aerotropolis (Kasarda, 2013). In relation to integration and innovation, a small number of interviewees also speak of the Durban Aerotropolis as a space for world-class logistics. Because the aerotropolis needs to meet the crucial demand for speed, agility and reliability in fulfilment of orders, infrastructure of this kind needs to be set up around airports (Kasarda, 2001b).

The function of the Durban Aerotropolis incorporates being a space for food production. Because South Africa is a food-insecure country, the master planning team for the Durban Aerotropolis identified a need for capitalising on rich agricultural potential. Within the project, the Dube AgriZone serves as an agricultural production zone for local and export 
markets. According to the Dube TradePort (2017), the AgriZone is said to be Africa's first integrated perishables supply chain and is home to the continent's largest climate-controlled growing area under glass.

Generally speaking, an aerotropolis is a city around an airport, however its specific function can only be defined by the stakeholders entrusted with the project. In this regard, the Durban Aerotropolis has been defined as a multifunctional enterprise fulfilling both aeronautical and commercial development functions. The findings show that integration and innovation are primary elements of the conceptualisation of the Durban Aerotropolis. Integration includes spaces of living, working and playing as well as the presence of basic services. Essentially, this integration can be understood as facilitating connection and assembling of the various functions to co-exist in space. Innovation, on the other hand, is evident in the presence of a world-class logistics platform, a sophisticated industrial area designated as an SEZ, and a food and agricultural complex. This innovation highlights processes of the Durban Aerotropolis through which 'dispersed parts' can be connected through logistics and emergent technologies. These 'dispersed parts' could be individuals, goods, companies or countries. Essentially, innovation is seen to facilitate a connection beyond fixed geographical spaces and physical boundaries.

\section{Conceptualisations of the form of the Durban Aerotropolis}

The functionality of the Durban Aerotropolis has driven the thinking on how its' purpose and functionality can and should be fulfilled on the ground. The key themes discussed here include perceptions of the Durban Aerotropolis form as a greenfields development, a quality urban space, and a corridor of economic development.

As a point of departure for the development planning, interviewees conceived of the aerotropolis as a greenfields space because it is a project whose form had been established on a commercial development site that was previously unused and had thus required rezoning from predominantly agricultural uses (CEO of the Dube TradePort, interview, 30. June 2016; Deputy Director of Policy and Planning, interview, 20. May 2016). In this characteristic, the Durban Aerotropolis is considered to be one of the few aerotropoli around the world using a greenfields site which is tailor-made as a platform to support air logistics and associated developments in an airport city. Taking the form of a greenfield site has created the opportunity to put in place a comprehensive plan that responds to and capitalises on the location of the airport on the edge of the eThekwini Municipality. EDTEA and its stakeholders and partners are thus able to manoeuvre and implement plans without any of the obstructions created by pre-existing built-up areas, as experienced in other airports in South Africa and beyond. However, being a greenfields site requires cognisance of the considerable time and money needed in the long-term for the aerotropolis to be fully developed. In addition, the greenfields nature of the aerotropolis also means that it is a space incorporating a multitude of natural habitats which need protection (EDTEA, 2016).

Kennedy et al. (2014) explain that the aerotropolis is essentially an airport-driven urban feature thus the nature of urbanity is important in planning, constructing and using the spaces of the Durban Aerotropolis. The Durban Aerotropolis Master Plan alludes to the form of the Durban Aerotropolis as reflective of a 'quality urban space' (EDTEA, 2016). The CEO of TKZN (interview 12. May 2016) argued that for the Durban Aerotropolis to become one of the best in the country and in the world, it has to be a sophisticated urban space that offers 
world-class service. This quality of urban space is defined by interviewees as being comprised of complete streets that equally serve the pedestrian and the car; that have a mix of uses in a compact, walkable area; and that have a memorable aesthetic or 'magnetism' (Aerotropolis Management Unit Programme Manager, interview, 18 May 2016). It is also envisaged as an urban space which is highly attractive to people.

By virtue of its form as a quality urban space, other respondents argued that the Durban Aerotropolis form therefore reflects an "airport city" or a city built around an airport. The "airport city" is characterised by commercial functions locating on and immediately around major airport sites (EDTEA, 2015). The airport city conceptualised by stakeholders as the nucleus or epicentre of the Durban Aerotropolis takes form of all the commercial functions located on the site of, and immediately surrounding, King Shaka International Airport and the Dube TradePort.

Further to the thinking that the Durban Aerotropolis takes the form of an urban development feature and an airport city, is the claim that the development of an aerotropolis facilitates the emergence of corridors, clusters and spines of airport-related businesses that create new urban forms close to major airports (Kasarda, 2000; Arend et al., 2004). The KZN Provincial Spatial Development Strategy (PSEDS) accordingly highlights the development of nodes and corridors in the province which emerge from the Durban Aerotropolis (KZN Planning Commission, 2011). The KZN Integrated Aerotropolis Strategy (EDTEA, 2015) speaks of these nodes as places such as Howick, Pietermaritzburg, Kranskop, Eshowe, Mandeni and Port Shepstone, with the nodes of La Mercy, Umhlanga, Tongaat and Ballito located immediately adjacent to the airport city. Economic activity will ripple from the core of the project, forming corridors of development between nodes and the airport city. In addition, plans for transportation upgrades to facilitate corridor development have been devised. These plans are focussed on road and rail alignments within a northern corridor which includes the highways which extend northwards to Richards Bay and onwards to Mozambique, and southwards along the KZN coast to the Port Shepstone area (EDTEA, 2016).

The findings presented above indicate that the form of the Durban Aerotropolis reflects a greenfield urban development project which, at its core, is an airport city from which corridors of economic activity spread to nodes of economic activity.

Taking the above-mentioned factors into account, the form of economic development mechanism or strategy that is seen by interviewees as capable of fulfilling the purpose of an integrated and mixed-use environment was identified as that of a quality urban space, or what is referred to as an airport-driven 'urban development' feature. In this context, the Durban Aerotropolis is thus an urban space whose development facilitates the emergence of corridors, clusters and spines of airport-related businesses that create new urban forms close to major airports or which connect existing nodes to economic activity in new ways.

\section{Conceptualisations of scale of the Durban Aerotropolis}

This section highlights two different conceptualisations of the scale of the Durban Aerotropolis that emerged from the primary data as predominant themes: (a) a scale which is fixed and bounded in space with defined size and a boundary, and (b) a scale defined by connection and looseness, and thus offering flexibility. 
Size-defined, fixed and bounded conceptualisations of scale are evident in Integrated Aerotropolis Strategy references to a footprint that requires differentiation between the airport city (a zone 'inside-the-fence') and the aerotropolis more broadly (the catchment area) (EDTEA, 2015). As explained earlier, the airport city form and function is characterised by commercial functions located on and immediately around the King Shaka International Airport site. The airside activity space includes shopping mall concepts merged into passenger terminals, retail (including streetscapes and upscale boutiques), restaurants (increasingly higher-end and themed), leisure (spas, fitness, recreation, cinemas and more) and culture (museums, regional art, musicians, chapels). On the landside are hotels and entertainment, office and retail complexes, convention and exhibition centres, time-sensitive goods processing facilities and industrial developments. These airside and landside activities are what is referred to as 'inside-the-fence' activities of the Durban Aerotropolis (see Figure 2).

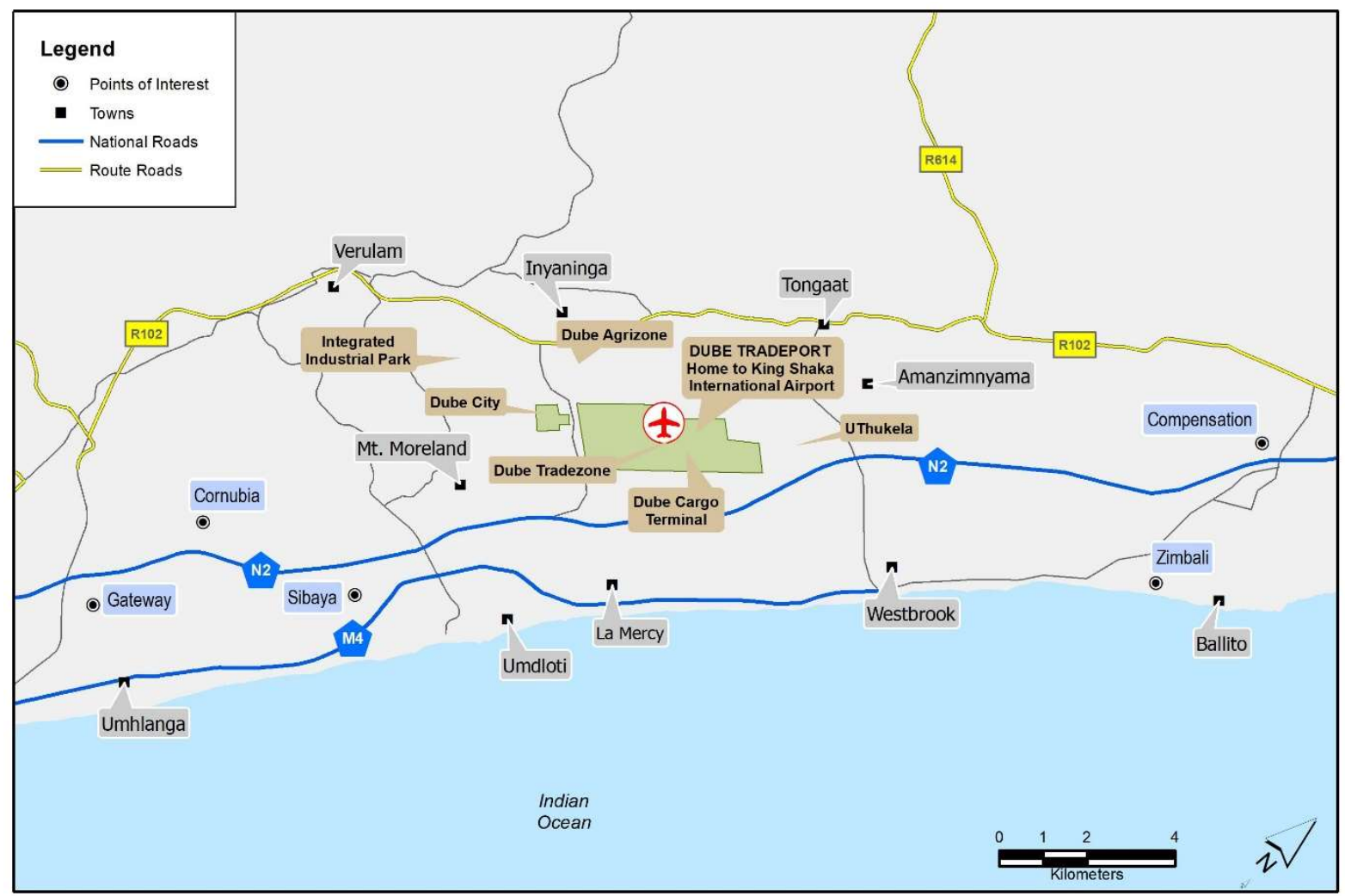

Figure 2: Inside the Fence spaces of the Durban Aerotropolis (illustration: Nomkhosi Luthuli).

In the KZN Integrated Aerotropolis Strategy (EDTEA, 2015) the Aerotropolis area is referred to as the catchment area. The defining criterion for the catchment area is the concept of the one-hour travel distance from King Shaka International Airport. The footprint depicted in Figure 3 shows that the catchment area is of a much larger scale than that of an 'inside-thefence' conceptualisation of the Durban Aerotropolis as the area covers almost all of the eThekwini Municipality, cuts across a number of municipal boundaries and further stretches up to the Richards Bay area in northern KwaZulu-Natal. The Aerotropolis shown in Figure 3 is based on the concept of a one-hour travel radius, a standardised measure for the scale of an aerotropolis established by John Kasarda, the originator of the aerotropolis concept (Kasarda, 2001a). The aim of this scaling-up of the Durban Aerotroplis to the extent of the one hour radius is to facilitate spatial and economic development planning which ensures that people can travel with ease between the airport and various destinations (nodes) and to reduce the 
travel time between the airport and nodes within the Areotropolis radius (EDTEA, 2015). These nodes include small towns and industrial nodes within KwaZulu-Natal such as Howick, Pietermaritzburg, Kranskop, Eshowe, Mandini and Port Shepstone. For this increasing connectivity to be achieved there has to be efficient, speedy and agile ground connectivity. Government is therefore being encouraged to invest substantially in road and rail infrastructure to achieve sufficient ground connectivity and, subsequently, to widen the King Shaka International Airport catchment area yet further.

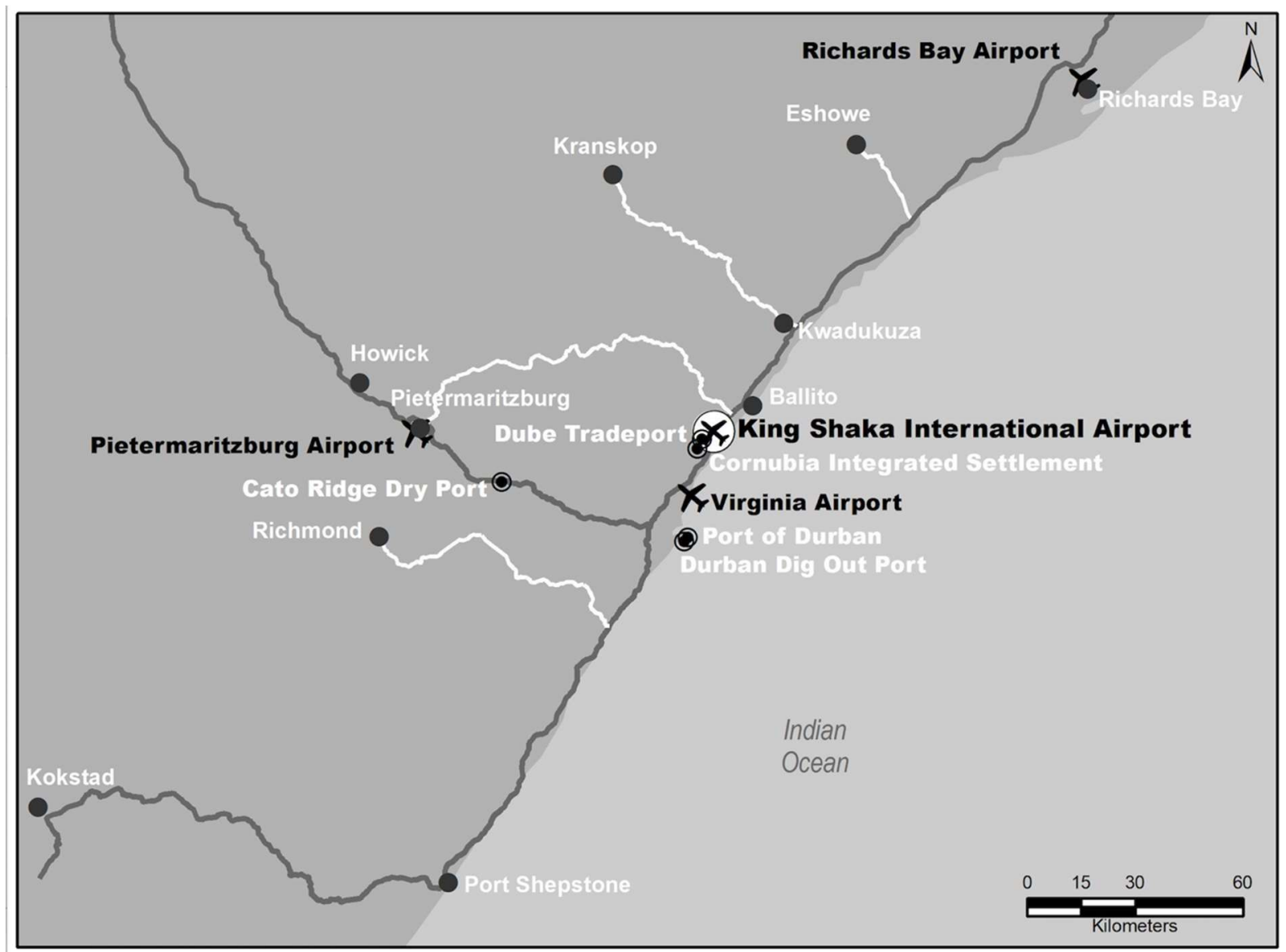

Figure 3 Durban Aerotropolis and the areas within the one-hour radius (illustration: Nomkhosi Luthuli).

The scale is also defined by the connections which are said to be loose and flexible. In relation to an unbounded sense of scale, there are specific places that are encompassed by the Durban Aerotropolis. The interviewees speak of these places in different ways. While some speak of compass points, others speak of their physical nature, as they are known colloquially, and also in terms of their political jurisdictions. In addition, places encompassed by the Durban Aerotropolis are described according to compass points, their physical nature and political jurisdictions. For example, places within the Durban Aerotropolis are described as stretching to cover areas to the "north, south and west of the airport" (Deputy Director of Research and Development, interview, 20 May 2016). This is a vague indication of the places incorporated within the area spoken of as the aerotropolis. Scale in these terms can be defined as loose and flexible.

The majority of the interviewees named the following areas as included within the Durban Aerotropolis boundary: Durban, Ballito, Ndwedwe, Tinley Manor, Stanger, Mandeni, Pietermaritzburg, Port Shepstone and Richards Bay. Respondents also refer to 'spillovers' in 
the sense that economic activity may well reach beyond the sense of a bounded 'in the fence' zone to other municipal jurisdictions in an active process of 'spreading outwards' from the core area. Additionally, some interviewees and the Masterplan speak of the influence of the Aerotropolis as reaching throughout the province of KwaZulu-Natal, into parts of Southern Africa and even globally (Aerotropolis Management Unit Programme Manager, interview 18 May 2016; Deputy Director of Research and Development, interview, 20 May 2016; EDTEA, 2016). They believed that the project will have an impact that reaches as far as Richards Bay, Pietermaritzburg and Port Shepstone on the South Coast. Others saw the impact stretching beyond of the borders of the country into Zimbabwe through its activities as a gateway for trade. In this perspective, although the naming of a location might be viewed as reflecting a more fixed scale, there are aspects of reach of the aerotropolis being understood as loose and flexible, more especially where interviewees refer to impact 'stretching' and spilling over to countries such as Zimbabwe and Nigeria. Overall, the distances between the core of the Durban Aerotropolis and these spaces is variable and the boundaries of the aerotropolis are thus viewed as loose and flexible, produced through multiple forms of connectivity rather than the designation of a specific aerotropolis space.

\section{Conceptualising a region for economic development through understanding the function, form and scale of the Durban Aerotropolis project}

The notion of the 'region' associated with the Durban Aerotropolis can be conceptualised through the investigation of the Durban Aerotropolis presented above. As described, the region inherent in the Durban Aerotropolis has a clear form and function but is made up of a scale which incorporates fixed and loose boundaries at varied distances from the core of the aerotropolis. This multifaceted description is indicative of the complexities of grasping the region as a defined concept.

Collectively, the form, function and scale of the Durban Aerotropolis speaks to different kinds of 'spaces'. These spaces are social constructs constituted through social relations and interactions in their own right (Varro \& Lagendijk, 2013). Without acknowledging these spaces, it is difficult to conceptualise the region associated with the Durban Aerotropolis, even as it is envisaged as a catalyst of regional economic development. Furthermore, although we understand regions as spatially contingent, Paasi (2011) suggests that the theoretical and empirical understandings of what regions are should be based on contextuality. Beginning with a consideration of space and context speaks to the formation of regions as constructed through the projects which are designed to contribute to their development. This is a region understood as an institutional fact (Van Langenhove, 2013), defined by its surface and boundaries and also by human agreement, in particular, by stakeholders of the project.

Airport city functions, or what is referred to as the function of the Durban Aerotropolis, produce the surfaces and boundaries of the region. These are the different components which make the Durban Aerotropolis region an integrated environment with a mixed-use function. The presence of spaces where people can live, work and play attest to there being residential spaces (to live), industrial spaces (to work) and entertainment spaces (to play).

The form of the Durban Aerotropolis assumes a relational form of space. Relational space is space which allows for what is called a 'throwntogetherness'. According to Hubbard et al. (2008), 'throwntogetherness' refers to the way in which diverse elements that cross 
categories such as the natural and social come together to foster a 'here' and 'now'. The elements of the scale and function come together in a space where they are interrelated. The relationship emerges from what was previously a greenfield site which took form of a quality urban space in which there are is a manifestation of a node and corridor of development which we ultimately refer to as the Durban Aerotropolis region.

This 'throwntogetherness' further assembles or brings together spaces of flows and spaces of places (Castells, 2000). The intention of the Durban Aerotropolis stakeholders to attract investors to their vicinity may potentially require interactions such as those that are facilitated through the spaces of flows. In this regard, the Durban Aerotropolis becomes a driver of air commerce and e-commerce and ensures that it meets the crucial demands for speed, agility and reliability in order fulfilment (Kasarda, 2001b). The space of flows virtually connects separate locations, and the interviewees articulate this complex process in layman terms, highlighted in the scalar concepts such as spillovers, influence, impact and reach.

The Durban Aerotropolis region as a whole can be further conceptualised in accordance with Castells' definition (2000: 453) of place as a "locale whose form, function and meaning are self-contained within the boundaries of physical contiguity". This essentially means that it is inherently characterised as specific place with a fixed purpose and bounded nature. Within this fixity of place, however, exists other spaces of places which interviewees have referred to in terms of compass points, in terms of their physical nature and in terms of their political jurisdictions.

In relation to the boundedness or unboundedness of the Durban Aerotropolis, the concepts of territoriality and relationality become important. The territorial view of region speaks to its boundedness in space. In the case of the Durban Aerotropolis, the airport city study area and the catchment area are two components of the region that can be spoken of as bounded. This is because these are the two absolute spaces of the Durban Aerotropolis, as highlighted above. The spaces of the Durban Aerotropolis are also socially constructed as bounded, relative space through the standardised scale of the one-kilometre radius provided by Kasarda. Beyond these absolute and relative spaces is a conception of the Durban Aerotropolis region as relational in that it is a complex network of concentrations of people and places incorporated in a flexible boundary or loosely connected through their related functionality (Suorsa, 2014).

Perceiving the Durban Aerotropolis region as relational means that it can be understood as an assemblage, which Allen et al. (1998: 50) define as a "product of the networks, interactions, juxtapositions and articulations of the myriad of connections through which all social phenomena are lived out". While Goodwin (2013) sees assemblages as overlapping institutional forms such as regional offices, agencies, boards and so on, Allen and Cochrane (2007) point out that these institutional forms are the foundation that holds down the fluid elements of global life in the interest of their region. This is true for the Durban Aerotropolis region, as it is a mixed-use space with a host of functions that ultimately serve the purpose of assisting KZN province to keep up with economic development, global business and investment trends.

The conceptualisation of the region inherent in the Durban Aerotropolis in relation to RED shows a process of delineation which is reflective of project scoping. In this regard, the region is treated as an endeavour whose form, function and scale are socially produced. Before planning of economic development for this region could be embarked on, it needed to 
be clearly defined; this definition could only be made by the interviewees from the Durban Aerotropolis, who also played a role in pronouncing the vision of the project and formalising this vision in the strategy documents of the Durban Aerotropolis project. Also instrumental in guiding the process of defining and delineating was the contribution made by John Kasarda as a pioneer of the aerotropolis concept.

These spaces all come together, or coalesce, in a 'throwntogetherness' of scale and function, coming together in a form within and through which they can have a relationship with each other. The 'throwntogetherness' also assembles spaces of flows and spaces of places. This is why the region in this instance can be understood as an assemblage consisting of overlapping institutional forms and the juxtaposition of connections.

\section{Conclusion}

Understanding the aerotropolis-based spatialities as social constructions which produce a 'region' facilitates a better understanding of the notion of the region as it exists within the heart of RED. The region produced through the Durban Aerotropolis project can be conceptualised as incorporating a geographical area, an economic interaction and an institutional jurisdiction. This region is a geographical area because its form is principally reflective of an urban space, or what Kennedy et al. (2014) refer to as an airport-driven urban feature. The region can be viewed as an economic interaction when we consider its function in the production of nodes and corridors of economic development. It is an institutional jurisdiction when we take cognisance of how it has become territory over which multiple stakeholders and actors of government have practical 'planning authority' through which spaces are designated as part of the aerotropolis and therefore, of its region. It is therefore useful for the wider practice of regional economic development to conceive of a region as a geographical space consisting largely of economic interaction and incorporating an institutional jurisdiction determined by the array of stakeholders.

Furthermore, in practising RED, the region can be defined and delineated through the function, form and scale attributed to an RED project. The function relates to the purpose of the regional intervention. Form refers to the kinds of spaces, development mechanisms or strategy that could assist in fulfilling the purpose. The scale of the region highlights the physical boundaries of the region defined by the project specifics but also clarifies its reach, which serves the purpose of determining which stakeholders to involve and ultimately defines the region of impact of an RED project. Overall, the theoretical and empirical conceptualisation of regions within regional economic development planning, policy-making and practice must draw on the specifics of contextuality to ensure its utility as a mechanism of economic development is not limited by fuzzy, simplistic or misconstrued notions of what the region entails.

Nomkhosi Luthuli, Graduate School of Business and Leadership, University of KwaZuluNatal,Durban, South Africa (LuthuliN5@ukzn.ac.za)

Jennifer Houghton, Graduate School of Business and Leadership, University of KwaZuluNatal, Durban, South Africa (jen.a.houghton@gmail.com) 


\section{References}

ACSA (2018) King Shaka International Airport- Passenger Traffic. Available at: http://www.airports.co.za/KSIA/Stats/King_Shaka_Airport_Passenger_Traffic_Mar18.pdf (accessed 13 July 2018).

Aerotropolis Management Unit Programme Manager (2016) interview, 20 May 2016.

Allen, J., \& Cochrane, A. (2007) Beyond the territorial fix: regional assemblages, politics and power. Regional studies, 41(9), pp.1161-1175. DOI: 10.1080/00343400701543348

Allen, J., Massey, D., Cochrane, A., Charlesworth, J., Henry, N. \& Sarre, P. (1998) Rethinking the region. London, Routledge.

Amin, A., Massey, D. \& Thrift, N. (2003) Decentering the nation: a radical approach to regional inequality. London, Catalyst.

Arend, M., Bruns, A. \& McCurry, J. W. (2004) The 2004 global infrastructure report. Site Selection Magazine, Sep. 2004.

Babbie, E. \& Mouton J. (2009) The practice of social research. Cape Town, Oxford University Press.

Bodhanya, S. (2015) Toolkit: Understanding Regional Economic Development. Available at: http://www.erln.co.za/attachments/article/246/ERLN\%20\%20Regional\%20Economic\%20Development \%20Position\%20Paper\%20\%20Dr\%20Shamim\%20Bodhanya.pdf (accessed 12 Dec. 2017).

Castells, M. (2000) The rise of the network society ( $2^{\text {nd }}$ ed.). Oxford, Blackwell Publishers Ltd.

CEO of the Dube TradePort (2016) Interview, 12 May 2016.

CEO of TKZN (2016) Interview, 12 May 2016.

Claval, P. (1998) An introduction to regional geography. Malden, MA, Wiley-Blackwell.

De Wet, J. P. \& Erasmus, Z. E. (2005) Towards rigour in qualitative analysis. Qualitative Research Journal, 5(1), pp. 27-40.

Director for Research and Development at EDTEA (2016) Interview, 1 July 2016.

Director of Policy and Planning at EDTEA (2016). Interview, 20 May 2016.

Dube TradePort (2017) We are Aerotropolis: KZN. Available at: http://aerotropoliskzn.com/ (accessed 17 Feb. 2017).

Dube TradePort Corporation (2018) Africa's most secure cargo terminal. Available at: http://www.dubetradeport.co.za/SiteFiles/152082/Dube\%20Cargo\%20Terminal\%20Brochure\%202018.p df (accessed 13 June 2017).

Economic Development, Tourism \& Environmental Affairs (2015) KwaZulu-Natal Integrated KZN Integrated Aerotropolis Strategy. Kwazulu-Natal.

Economic Development, Tourism \& Environmental Affairs (2016) Durban Aerotropolis Masterplan $1^{\text {st }}$ Draft. KwaZulu-Natal.

Farrell, M., Hettne, B. \& Van Langenhove, L. (2005) Global politics of regionalism: theory and practice. London, Pluto Press.

Goodwin, M. (2013) Regions, territories and relationality: exploring the regional dimensions of political practice. Regional Studies, 47(8), pp. 1181-1190. DOI: 10.1080/00343404.2012.697138

Goodwin, M., Jones, M. \& Jones, R. (2005) Devolution, constitutional change and economic development: explaining and understanding the new institutional geographies of the British state. Regional Studies, 39(4), pp. 421-436. DOI: 10.1080/00343400500128432

Gregory, K.J. (2000) The changing nature of physical geography. Oxford, Oxford University Press.

Hanly, D. (2015) An investigation into the application of the aerotropolis strategy to the Cape Town International Airport from a global south urban planning perspective. Doctoral Thesis. Cape Town, University of Cape Town, Engineering and Built Environment.

Hooghe, L. \& Marks, G. (2009) A postfunctionalist theory of European integration: From permissive consensus to constraining dissensus. British Journal of Political Science, 39(1), pp. 1-23.

DOI: $10.1017 / \mathrm{S} 0007123408000409$

Hubbard, P., Kitchin, R. \& Valentine, G. (eds.) (2008) Key texts in human geography. London, Sage Publications.

Hudson, R. (2006) Regions and place: music, identity and place. Progress in Human Geography, 30(5), pp. 626-634. DOI: 10.1177/0309132506070177

Kasarda, J. (2000) Planning the Aerotropolis. Airport World, 5, pp. 52-53.

Kasarda, J. (2001a) From Airport City to Aerotropolis. Airport World, 6, pp. 42-45.

Kasarda, J. (2001b) Logistics and the rise of Aerotropolis. Real Estate Issues, winter 2000/2001, pp. 43-48.

Kasarda, J. (2006) Airport cities and the aerotropolis. Available at: http://m.aerotropolis.com/files/2006_07_AirportCities.pdf (accessed 11 Dec. 2017).

Kasarda, J. (2013) Airport cities: The evolution. Airport World, 18. Available at: http://www.aerotropolis.com/files/AirportCitiesTheEvolution.pdf (accessed 11 Feb. 2017). 
Kasarda, J. D. \& Appold, S. J. (2014) "Planning a competitive Aerotropolis." The economics of international airline transport. Emerald Group Publishing Limited, pp. 281-308. DOI: 10.1108/S2212160920140000004010

KZN Planning Commission (2011) Provincial Spatial Development Framework. Available at: http://www.kznppc.gov.za/images/downloads/PGDS\%20Annexure\%20C\%20\%20Provincial\%20Spatial \%20Development\%20Framework\%20(Draft\%202).pdf (accessed 13 Dec. 2017).

Kennedy, L., Robbins, G., Bon, B., Takano, G., Varrel, A. \& Andrade, J. (2014) Megaprojects and urban development in cities of the South. Thematic Report, WP2. Chance2Sustain. Bonn, EADI.

Keating, M. (1998) Is there a regional level of government in Europe. Regions in Europe, pp. 11-29.

Jones, M., \& MacLeod, G. (2004) Regional spaces, spaces of regionalism: territory, insurgent politics and the English question. Transactions of the Institute of British Geographers, 29(4), pp. 433-452. DOI: $10.1111 / \mathrm{j} .0020-2754.2004 .00140 . x$

Latour, B. (1999) On recalling ANT. The Sociological Review, 47(S1), pp. 15-25. DOI: 10.1111/j.1467954X.1999.tb03480.x

Luthuli N. H. (2013) Special Economic Zones in Development: An exploration of Dube TradePort, KZN, in relation to its stakeholders, Master's thesis. Durban, University of KwaZulu-Natal, Graduate School of Business and Leadership.

Macleod, G. \& Jones, M. (2007) Territorial, scalar, networked, connected: In what sense a 'regional world'?. Regional Studies, 41(9), pp. 1177-1191. DOI: $10.1080 / 00343400701646182$

Massey, D. (2005) For space. London, Sage Publication.

Mattli, W. (1999) The logic of regional integration: Europe and beyond. Cambridge, Cambridge University Press. DOI: 10.1017/CBO9780511756238

Menon, A. (2014) An aerotropolis evaluation tool for decision-makers. Civil Engineering, 22 (8), pp. 48.

Miles, M. B. \& Huberman, A. M. (1994) Qualitative data analysis: An expanded sourcebook. Thousand Oaks, CA, Sage Publications.

Nel, E. \& Rogerson, C. M. (2005) Pro-poor local economic development in South Africa's cities: policy and practice. Africa Insight, 35(4), pp. 15-20.

Nel, E. \& Rogerson, C. M. (2016) The contested trajectory of applied local economic development in South Africa. Local Economy, 31(1-2), pp. 109-123. DOI: 10.1177/0269094215623729

Olberding, J. C. (2002) Does regionalism beget regionalism? The relationship between norms and regional partnerships for economic development. Public Administration Review, 62(4), pp. 480-491. DOI: $10.1111 / 0033-3352.00201$

Paasi, A. (1986) The institutionalization of regions: a theoretical framework for understanding the emergence of regions and the constitution of regional identity. Fennia, 164, pp. 105-46. DOI: 10.11143/9052

Paasi, A. (2002) Place and region: regional worlds and words. Progress in Human Geography, 26(6), pp. 802811. DOI: $10.1191 / 0309132502 \mathrm{ph} 404 \mathrm{pr}$

Paasi, A. (2004) Place and region: looking through the prism of scale. Progress in Human Geography, 28(4), pp. 536-546. DOI: 10.1191/0309132504ph502pr

Paasi, A. (2009) Bounded spaces in a 'borderless world': border studies, power and the anatomy of territory. Journal of Power, 2(2), pp. 213-234. DOI: 10.1080/17540290903064275

Paasi, A. (2011) The region, identity, and power. Procedia-Social and Behavioral Sciences, 14, pp. 9-16. DOI: $10.1016 /$ j.sbspro.2011.03.011

Peneda, M., Reis, V. \& Macário, M. (2011) Critical factors for development of airport cities. Transportation Research Record: Journal of the Transportation Research Board, 2214, pp. 1-9. DOI: 10.3141/2214-01

Rogerson, C. M. (2010) Local economic development in South Africa: Strategic challenges. Development Southern Africa, 27(4), pp. 481-495. DOI: 10.1080/0376835X.2010.508580

Rogerson, C. M. \& Rogerson, J. M. (2012) Business development and local economic development in South Africa: addressing the disconnect. Acta Academica, 44(2), pp. 41-69.

Suorsa, K. (2014) The concept of 'region' in research on regional innovation systems. Norsk Geografisk Tidsskrift-Norwegian Journal of Geography, 68(4), pp. 207-215. DOI: 10.1080/00291951.2014.924025

Thomas, N. J., Harvey, D. C. \& Hawkins, H. (2013) Crafting the region: creative industries and practices of regional space. Regional Studies, 47(1), pp. 75-88. DOI: 10.1080/00343404.2012.709931

Urry, J. (2007) Mobilities. Cambridge, Polity Publishers.

Van Langenhove, L. (2013) Building regions: the regionalization of the world order. London, Routeledge.

Varró, K. \& Lagendijk, A. (2013) Conceptualizing the region-in what sense relational?. Regional Studies, 47(1), pp. 18-28. DOI: 10.1080/00343404.2011.602334 